NBER WORKING PAPER SERIES

\title{
COUNTER-SUICIDE-TERRORISM: EVIDENCE FROM HOUSE DEMOLITIONS
}

\author{
Efraim Benmelech \\ Claude Berrebi \\ Esteban Klor \\ Working Paper 16493 \\ http://www.nber.org/papers/w16493
}

\author{
NATIONAL BUREAU OF ECONOMIC RESEARCH \\ 1050 Massachusetts Avenue \\ Cambridge, MA 02138 \\ October 2010
}

We are grateful to Eli Berman, Javier Gardeazabal, Laura Jones Dooley, David Laibson, Ariel Merari, Eva Milgrom, Paul Milgrom, Daniele Paserman, and Todd Sandler for very helpful suggestions. We have also benefited from comments from participants in the Workshop on Political Economy of Counter Insurgency at Princeton University, the Workshop on Political Economy of Terrorism and Insurgency at University of California, San Diego, the Workshop on Terrorism Policy at University of Texas, Dallas, the National Bureau of Economic Reseach summer Workshop on the Economics of National Security, the Western Economic Association meetings, and seminars at Harvard University. We thank the Israeli Security Agency for data on suicide terrorists and B'Tselem (The Israeli Information Center for Human Rights in the Occupied Territories) for data on house demolitions. Esteban Klor is grateful for the warm hospitality of Boston University and the National Bureau of Economic Research while working on this project. The views expressed herein are those of the authors and do not necessarily reflect the views of the National Bureau of Economic Research.

NBER working papers are circulated for discussion and comment purposes. They have not been peerreviewed or been subject to the review by the NBER Board of Directors that accompanies official NBER publications.

(C) 2010 by Efraim Benmelech, Claude Berrebi, and Esteban Klor. All rights reserved. Short sections of text, not to exceed two paragraphs, may be quoted without explicit permission provided that full credit, including $\odot$ notice, is given to the source. 
Counter-Suicide-Terrorism: Evidence from House Demolitions

Efraim Benmelech, Claude Berrebi, and Esteban Klor

NBER Working Paper No. 16493

October 2010

JEL No. H56,K42,O53

\begin{abstract}
$\underline{\text { ABSTRACT }}$
This paper examines whether house demolitions are an effective counterterrorism tactic against suicide terrorism. We link original longitudinal micro-level data on houses demolished by the Israeli Defense Forces with data on the universe of suicide attacks against Israeli targets. By exploiting spatial and time variation in house demolitions and suicide terror attacks during the second Palestinian uprising, we show that punitive house demolitions (those targeting Palestinian suicide terrorists and terror operatives) cause an immediate, significant decrease in the number of suicide attacks. The effect dissipates over time and by geographic distance. In contrast, we observe that precautionary house demolitions (demolitions justified by the location of the house but not related to the identity or any action of the house's owner) cause a significant increase in the number of suicide terror attacks. The results are consistent with the view that selective violence is an effective tool to combat terrorist groups, whereas indiscriminate violence backfires.
\end{abstract}

Efraim Benmelech

Harvard University

Department of Economics

Littauer 233

Cambridge, MA 02138

and NBER

effi_benmelech@harvard.edu

Claude Berrebi

The Federmann School of

Public Policy and Government

Hebrew University

Mount Scopus

Jerusalem ISRAEL 91905

and RAND Corporation

Claude_Berrebi@rand.org
Esteban Klor

Dept. of Economics

Hebrew University

Mount Scopus

Jerusalem ISRAEL 91905

eklor@mscc.huji.ac.il 


\section{Introduction}

Although it is commonly argued that government policies to deter terrorism and disrupt the operations of terror organizations tend to be effective (Ganor, 2005), alternative theoretical models suggest that they may have a boomerang effect. According to this view, harsh measures of counterterrorism backfire by fostering hatred and attempts to exact revenge (Siqueira and Sandler, 2006). In particular, while counterterrorism policies typically affect the general population, the effectiveness of counterterrorism policies depends on their ability to target terror organizations directly. ${ }^{1}$

However, despite the wide interest that counterterrorism policies draw and the abundance of related theoretical studies, there is little empirical evidence on the effectiveness of counterterrorism measures. Assessing the effectiveness of counterterrorism policies requires detailed micro-level data on terror attacks and counterterrorism operations. Unfortunately, such detailed data are typically not publicly available.

This paper attempts to fill this gap by linking novel micro-level data on house demolitions (a policy used by the Israeli Defense Forces [IDF] to combat and deter terrorism) and suicide attacks, empirically documenting the effects of house demolitions on future suicide attacks. We differentiate between the two main types of house demolitions carried out by the IDF: precautionary demolitions and punitive house demolitions. Precautionary demolitions are intended to prevent the launching of attacks from specific locations and are not related to activities carried out by the owners or occupants of the houses being demolished. In contrast, in punitive house demolitions, the IDF demolishes or seals houses that were home to Palestinian suicide terrorists or to individuals suspected, detained, or convicted of involvement in violent acts against Israelis.

Our analysis is based on original micro-level data. We use a longitudinal micro-level data set containing information on all punitive house demolitions during the second Palestinian uprising as well as all precautionary house demolitions between 2004 and 2005. For each house demolished we know the exact location of the house, the timing of the demolition, the house's size, and the number of its residents. We link this data set with data on the universe of suicide terrorists during the same time period, including each terrorist's timing of the attack and locality

\footnotetext{
${ }^{1}$ See, e.g., Bueno de Mesquita and Dickson (2007) and Fearon and Laitin (2003).
} 
of residence. We augment our data with localities' specific economic and demographic data, as well as with longitudinal variation of other counterterrorism measures imposed by the IDF. This detailed data set allows us to use time and spatial variation to identify and quantify the effectiveness of house demolitions as a deterrence policy of counterterrorism.

We find that punitive house demolitions lead to fewer suicide attacks in the month following the demolitions. The effect of house demolition is significant and sizeable - a standard deviation increase in punitive house demolitions leads to a decrease of 11.7 percent in the number of suicide terrorists originating from an average district. Intriguingly, we find that in contrast to the deterrent effect of punitive house demolitions, precautionary demolitions (which are not related to activities of the houses' owners and occupants) are associated with more suicide attacks. In particular, our estimates show that a standard deviation increase in precautionary house demolitions leads to a 48.7 percent increase in the number of suicide terrorists from an average district.

Our results are robust to alternative measures of house demolitions, such as the number of housing units demolished, number of residents affected, and the area size of demolished houses. The results are also robust to different specifications including a battery of control variables, counterterrorism measures, and fixed effects. Moreover, we examine the robustness of our results under alternative counterfactuals, estimate the persistence of the effects, and test whether these effects change directions over time.

The results indicate that, when targeted correctly, counterterrorism measures such as house demolitions provide the desired deterrent effect. When used indiscriminately, however, house demolitions lead to the radicalization of the population and backfire, resulting in more subsequent attacks.

The rest of the paper is organized as follows. Section 2 highlights the institutional details of house demolitions. Section 3 surveys related literature on counterterrorism policies. Section 4 describes the data and summary statistics. Section 5 presents the empirical analysis, and the last section concludes. 


\section{House Demolitions: Background ${ }^{2}$}

The Israel Defense Forces carries out two main types of house demolitions: house demolitions in "clearing operations" and punitive house demolitions. ${ }^{3}$

According to official IDF statements, house demolitions in clearing operations are intended to meet military needs. In particular, such house demolitions are intended to prevent the launching of attacks from these houses and areas. These demolitions are not related in any way to activities carried out by the owners or occupants of the houses being demolished. During the period 2000-2005, clearing operations took place primarily in the Gaza Strip to create "no go areas." Houses were demolished mostly along the Egyptian border in the south; around Israeli settlements, army posts, and roads that were used by settlers and IDF forces throughout Gaza before the Israeli evacuation of 2005; and in the northern Gaza Strip, in areas from which mortar rockets (mainly Kassam) have been fired, targeting Israeli communities in southern Israel. We refer to such demolitions here as "precautionary house demolitions." We have data on precautionary house demolitions for the years 2004 and 2005.

The second type of demolition is "punitive house demolitions." In punitive house demolitions, the IDF demolishes or seals houses that were home to Palestinians suspected of, detained in connection with, or convicted of involvement in violent acts against Israelis, regardless of the results. These acts include suicide bombings that caused many civilian fatalities as well as thwarted attacks against soldiers or civilians. The demolished houses belong not only to perpetrators but to individuals accused of involvement in an attack, either by planning it, dispatching the perpetrators, or providing assistance to the responsible terrorist cell. We have data on all punitive house demolitions between the years 2000 and 2005.

\subsection{The Evolution of House Demolitions: From 1945 to the Second Intifada}

The policy of house demolitions in the region began during the British Mandate. In 1945 the acting British high commissioner for Palestine enacted emergency defense regulations that

\footnotetext{
${ }^{2}$ This section draws mostly on Darcy (2003) and Shnayderman (2004).

${ }^{3}$ A third type of demolition is administrative house demolitions of houses built without a building permit. These demolitions occur almost exclusively in East Jerusalem and are not related to security concerns. We do not include administrative house demolitions in our analysis because they are not security related, there is not geographic variation of these demolitions, and there are no good micro-level data on them.
} 
granted authorities the power to conduct searches, make arrests, establish military courts to try civilians without right of appeal, close off areas, deport individuals, impose curfews, and demolish houses. In particular, regulation 119(1) allowed the military to seize and destroy houses, structures, and land as punishment for illegal acts.

The Israeli security forces began conducting punitive house demolitions in 1967, right after the Six Days' War, and demolished almost 1,400 houses in the late 1960s. Although the policy remained in place, punitive house demolitions were rare from the early 1970s until 1987. With the beginning of the first Intifada in December 1987, the IDF significantly increased the use of punitive house demolitions to punish and deter further acts of violence, resulting in almost 500 demolitions in the years 1988-1992. There were only a few house demolitions between 1993 and 1997, and the policy was discontinued from 1998 until September 2001.

In response to the wave of violence of the second Intifada that began in October 2000, the IDF informally renewed punitive house demolitions. The first house demolished during the second Intifada belonged to a Palestinian suicide bomber who killed 21 Israelis when he blew himself up in a discotheque in Tel Aviv. ${ }^{4}$ The political-security cabinet of the Israeli government officially renewed the policy of punitive demolitions on July 31, 2002, right after a terror attack at the Hebrew University of Jerusalem killed nine Israelis.

The use of house demolitions as a counterterrorism tool has been hotly debated inside and outside of Israel. Several human rights organizations have repeatedly challenged its legality. In cases argued before the Israeli Supreme Court of Justice, these organizations have asserted that the policy of house demolitions constitutes a war crime because it punishes innocent individuals for acts committed by others (Darcy, 2003). ${ }^{5}$

In defense of this policy, Israeli officials repeatedly argue that the policy of house demolitions falls within the exception to article 53 of the fourth Geneva Convention. According to the IDF, the demolition of houses of terrorists and terror operatives is a crucial counterterrorism tool for deterring terrorism in general and suicide terrorism in particular. The

\footnotetext{
${ }^{4}$ This is the house of Sa'id al-Hutri, which was demolished on October 23, 2001, in Qalqiliya.

${ }^{5}$ These arguments are supported by article 53 of the Fourth Geneva Convention Relative to the Protection of Civilian Persons in Time of War, which states that occupying states are forbidden to destroy property except where such destruction is rendered absolutely necessary by military operations.
} 
Supreme Court of Justice has repeatedly declined to interfere with the IDF's operational military considerations (Nabot, 2003).

\section{The Effectiveness of Counterterrorism Policies: Related Literature}

Although the policy of house demolition has been vigorously debated in political and legal arenas, there are no systematic studies ascertaining whether house demolitions are effective in stopping terrorism in general and suicide terrorism in particular (Harel and Isacharoff, 2004). The Israeli government and the IDF have repeatedly argued before the Supreme Court of Justice and in the popular press that the policy is effective, although they acknowledge that "it is impossible to know the exact figures of potential terrorists that have been deterred from perpetrating attacks by this prevention tactic." "In support of the deterrent effect of house demolitions, government and military officials often cite anecdotal evidence in which relatives of individuals recruited to commit suicide attacks have contacted the IDF and cooperated with the military in an attempt to stop the attack and thus save their houses from being demolished (Alon, 2002).

Opponents argue that demolishing houses backfires, since it increases the Palestinians' hatred of and animosity toward Israel. For example, Shalev's report of 1991 relies on seven data points from the first Intifada to argue that, in the aftermath of house demolitions, the number of violent events against Israelis did not decrease and sometimes even increased.

Evaluating the effectiveness of house demolitions in particular, and counterterrorism in general, is a challenging empirical task. It is difficult to obtain micro-level data since security forces are reluctant to release classified counterterrorism information. Even when data are available, the effect of counterterrorism policies remains unclear because terror organizations react to the new conditions by choosing different targets and modes of attack. ${ }^{7}$

\footnotetext{
${ }^{6}$ Cited from "IDF Spokesperson's response to the House Demolition Report," in Shnayderman (2004, 64).

${ }^{7}$ There is a growing literature showing that terror groups strategically adapt to counterterror policies. See, among others, Baliga and Sjöström (2010), Berman (2009), Berman and Laitin (2008), and Enders and Sandler $(1993,2004)$. The related theoretical literature on counterterrorism takes terror groups' strategic reaction into account for the design of efficient counterterror policies (see, e.g., Bueno de Mesquita (2007) and Powell (2007a, 2007b)).
} 


\section{Data}

We use a novel data set on houses demolished between the years 2000 and 2005 as well as data containing the universe of Palestinians suicide terrorists during the same time period. We augment these data with information on other counterterrorism measures, as well as economic and demographic characteristics of Palestinian localities.

Our data on house demolitions were obtained from B’Tselem, a nongovernmental Israeli human rights organization that monitors and collects data on the Israeli-Palestinian conflict. Although several studies have used B'Tselem's data on Israeli and Palestinian fatalities, ours is the first to use B'Tselem's detailed micro-data on house demolitions. ${ }^{8}$

The data include all punitive house demolitions between September 2000 and December 2005 and all precautionary house demolitions for the years 2004 and 2005. For every house demolition (both punitive and precautionary) we know the date and location of the house demolished, as well as the number of units in each house, the number of residents in the house, and the house's size.

Table 1 depicts the yearly variation of house demolitions during the second Intifada. Punitive house demolitions vary significantly over time during this period. The IDF renewed the policy of punitive house demolitions in October 2001, so there were no punitive house demolitions in 2000 and just six punitive house demolitions in 2001. The number of houses demolished increases sharply to 235 houses in 2002, the most violent year of the second Intifada. Whereas the high number of punitive house demolitions remains almost unchanged in 2003, there is a monotonic decline in the number of punitive house demolitions in the final two years of the second Intifada.

For each house, we list the number of apartment units, the number of residents, and the size of the house. Not surprisingly, these related measures of the severity of punitive house demolitions are highly correlated and show almost the same fluctuation over time. The correlation between house demolitions and apartment units demolished is 0.99, and the correlations between house demolitions and the number of residents in the demolished housed and the size of the houses demolished are 0.72 and 0.88 , respectively.

\footnotetext{
${ }^{8}$ For studies that use B'tselem's data on Israeli and Palestinian fatalities see, among many others, Becker and Rubinstein (2008), Benmelech et al. (2010), Gould and Klor (2010), Gould and Stecklov (2009), and Jaeger and Paserman (2006 and 2008).
} 
Table 1 also presents the number of precautionary house demolitions in 2004 and 2005. The table shows a high number of precautionary demolitions in 2004 and a large decline in 2005. Most of these demolitions occurred in the Gaza Strip (only 25 of the 1,172 occurred in the West Bank). The large number of demolitions in the Gaza Strip is primarily the result of the IDF's attempt to stop the smuggling of weapons and explosives from Egypt to Gaza through tunnels. In creating a 300-meter buffer zone along the border between Gaza and Egypt, the Israeli army demolished 619 houses in the southern district of Rafah between March and November 2004 (Human Rights Watch, 2004).

In the bottom panel of Table 1 we present data on suicide terrorists, Israeli fatalities, and Palestinian fatalities. The data on Palestinian suicide terrorists were constructed by Benmelech and Berrebi (2007) from reports of the Israeli Security Agency (ISA) and detail the biographies of all Palestinian suicide terrorists who attacked (or attempted to attack) targets in Israel, the West Bank, and the Gaza Strip between September 2000 and December 2005. The data contain information on terrorists' characteristics, targets' characteristics, and outcome of the attacks. In particular, for the 150 suicide terrorists in our data set we know their place of residence and the date of the attack.

As expected, the number of punitive demolitions is highly correlated with the number of suicide terrorists. That is, we observe a yearly increase in the number of suicide terrorists up until 2002 and a monotonic decrease after that peak for all subsequent years. We observe similar patterns of the evolution of violence when we focus on the fluctuations of Israeli and Palestinian fatalities over time.

The spatial heterogeneity of suicide terrorists and punitive house demolitions is illustrated in Figure 1. Listed in parentheses are both the number of suicide terrorists who originated from (first number) and the number of punitive house demolitions carried out in each of the ten districts in the West Bank, the five districts in the Gaza Strip, and East Jerusalem (second number).

There is a high geographic variation with respect to the district of origin of suicide terrorists and of corresponding house demolitions, especially in the West Bank. Some districts are violent (Jenin, Nablus, Bethlehem, and Hebron), with a high number of suicide terrorists and punitive house demolitions, while other districts are fairly calm (Tubas, Jericho, and Salfit). 
Districts in the Gaza Strip are more homogenous than those in the West Bank in terms of the number of both suicide terrorists and punitive house demolitions.

Table 2 refines the geographical description of Figure 1 by reporting summary statistics on the number of suicide terrorists originating from a locality, the number of Israeli-induced Palestinian fatalities, and the number of house demolitions for each locality in the West Bank and Gaza Strip. ${ }^{9}$

Violence varied substantially across localities. The average number of suicide terrorists originating from a locality is 0.218 . Forty-three of the 683 localities had at least one suicide terrorist, and the maximum number of suicide terrorists originating from a locality (Nablus) is 30. The average number of Israeli-induced Palestinian fatalities is 4.9 , and the maximum is 490 (Ashati Refugee camp in the Gaza district). There are 0.9 punitive house demolitions in the average locality affecting 5.96 residents.

Table 3 restricts the sample to the 43 localities from which at least one suicide terrorist originated. The average number of suicide terrorists per locality in this subsample is 3.5, and the median is 2. There were on average 63.5 Israeli-induced Palestinian fatalities in these localities. The average number of punitive house demolitions is 10.63, and the average number of precautionary house demolitions is 25.58. Likewise, about 70 local residents were directly affected by punitive demolitions within a locality, and on average 239.5 residents were directly affected by precautionary demolitions during the period at issue.

In our empirical estimation we augment the data on suicide bombers and house demolitions with economic and demographic variables from the Palestinian Labor Force Survey (PLFS) of the West Bank and Gaza Strip. ${ }^{10}$ Table 4 displays summary statistics of the economic and demographic variables of interest for all districts and provides a general overview of Palestinian economic and demographic conditions during second Intifada. We observe a

\footnotetext{
${ }^{9}$ We classify localities using the 1997 Palestinian Census. Accordingly, there are 683 localities in East Jerusalem, the West Bank, and the Gaza Strip.

10 This survey, administered by the Palestinian Central Bureau of Statistics (PCBS), covers a representative sample of the Palestinian population. The survey has been conducted every quarter since 1995 and provides information on a sample of about 22,000 individuals aged 15 and above residing in East Jerusalem, the West Bank, and the Gaza Strip. Since our empirical analysis focuses on the second Intifada, we use data from all quarterly surveys between the years 2000 and 2005, with a total of more than 500,000 individual-quarter observations. We use these micro-level data to calculate economic and demographic variables at the district level.
} 
relatively young population with low average years of schooling and a low unemployment rate due largely to extremely low labor force participation.

In the bottom row of Table 4 we report summary statistics on the number of curfews days per district per quarter. The data on curfews was obtained from the United Nations Office for the Coordination of Humanitarian Affairs (OCHA). ${ }^{11}$ OCHA provided data on total hours under curfew by district by month between May 2002 and December 2005. Over this period, the average number of curfew days in a month within a district was 1.341 , and the maximum was 4.6 days (in Hebron).

\section{The Effect of House Demolitions on the Number of Suicide Attacks}

\subsection{Empirical Framework}

To test the relationship between house demolitions and the number of suicide terrorists we focus on district-month cells (or localities-month cells). Our baseline regressions identify the effect of house demolitions within a district on future suicide attacks originating from that district. Given that the number of attacks originated from a district at a particular month is a nonnegative integer, we estimate Poisson regression models.

Formally, we estimate different variants of the following baseline specification:

$$
\left.E \text { [suicide terrorists }{ }_{i, t} \mid \mathbf{x}_{i, t-1}\right]=\exp \left(\mathrm{HD}_{i, t-1} \beta_{1}+\mathrm{x}_{\mathrm{i}, \mathrm{t}-1} \beta_{2}+\lambda_{\mathrm{i}}+\gamma_{\mathrm{t}}\right)
$$

where suicide terrorists $s_{i, t}$ is the number of suicide terrorists that originate from district $i$ in month $t$; $\mathrm{HD}_{i, t-1}$ is the number of punitive house demolitions in district $i$ in month $t-1$; and $\mathrm{x}_{i, t-1}$ represents the other explanatory variables in the model that are used to control for potentially confounding factors. These include Israeli-induced Palestinian fatalities, demographic and economic characteristics, and Israeli security measures that vary across districts and time, all of which are listed in Table 4. $\lambda_{i}$ is a district fixed effect that controls for districts' unobservable characteristics that are time-invariant; $\gamma_{t}$ is a year fixed effect that absorbs common fluctuations of violence over time. Hence, by including fixed effects for each district and year, we essentially examine whether variation over time in punitive house demolitions within a district is correlated with variation over time within a district of suicide terror attacks, while controlling for the

\footnotetext{
${ }^{11}$ OCHA coordinates humanitarian action on behalf of the United Nations in many countries. As one of its responsibilities, the OCHA office in the West Bank and Gaza Strip monitors closures and curfews imposed on the Palestinian population.
} 
common trend in violence across districts and a rich set of districts' characteristics. In some of the specifications in the tables below we include district-specific time trends, thus showing that the results are robust to an alternative identifying assumption. Last, in all specifications we cluster the error term at the district level to capture nonsystematic determinants of the number of suicide terrorists.

\subsection{Main Results}

We present the results from estimating the impact of punitive house demolitions on the number of suicide terrorists from the same district in subsequent months in Table 5. We estimate a panel Poisson model controlling - depending on the specification - for district fixed effects, year fixed effects, district-specific linear time trends, and districts' economic and demographic characteristics (unemployment, percentage employed in Israel, average years of schooling, average age, and fraction of males and married individuals in the district's population). In some specifications we also control for other security-related measures (in addition to house demolitions) for which data are available: (1) the number of Israeli-induced Palestinian fatalities, and (2) the number of days with a curfew. ${ }^{12}$

The effect of punitive house demolitions on the number of suicide terrorists is not statistically significant when we only control separately for either district or year fixed effects (Columns 1-3). In fact, without controlling for district fixed effects, we observe a positive correlation between punitive house demolitions and number of suicide terrorists. This result is likely to be caused by an omitted variable bias, since more violent districts obviously have more punitive house demolitions and a higher number of suicide terrorists. Nonetheless, a naive interpretation of this positive correlation is sometimes being used in public discourse as proof that house demolitions backfire.

When we control for district fixed effects (to account for unobserved underlying heterogeneity across districts) and year fixed effects (to account for common fluctuations over time of the variables of interest), we see that punitive house demolitions in a given district significantly decrease the number of suicide terrorists who originate from that district. This effect

\footnotetext{
12 The inclusion of days with a curfew into the model considerably lowers the number of observations from 1,008 district-month observations to 704 because this variable is available only from May 2002 onward.
} 
is not only statistically significant but of an important magnitude. In particular, the estimated rate ratio implies that the marginal punitive house demolition lowers the number of suicide terrorists originating from a district in the following month by a factor of 0.941 . This effect implies that a standard deviation increase in the number of punitive house demolitions (which is equal to 2.04) causes a decrease of 11.7 percent in the number of suicide terrorists originating from an average district-month cell.

The negative effect of punitive house demolitions on the number of subsequent suicide terrorists is qualitatively and quantitatively robust to the inclusion of additional controls, such as demographic and economic characteristics (Column 5), as well as other proxies for the security situation at the district level (Column 7). Moreover, when we include district-specific time trends, the result (Column 6) is also robust to different identifying assumptions that are based on deviations of house demolitions and the number of suicide terrorists from districts' specific trends (and not only the districts' averages, as in the other columns).

In Table 6 we repeat the same specifications of Columns 4 to 7 in Table 5 but focus on the other available measures for the severity of house demolitions. The results confirm that the main conclusions from Table 5 are robust to different measures of house demolitions and across different specifications. That is, punitive house demolitions have a significant deterrent effect on suicide terrorism regardless of whether we focus on the number of apartment units, the number of residents, or the size of the houses being demolished. The point estimates for each measure are not affected by the additions of demographic and economic controls or other measures of counterterrorism. The estimates are also robust to the inclusion of district-specific time trends.

We analyze the data using both district-month and locality-month aggregations. Tables 7 and 8 repeat the regressions in Tables 5 and 6, respectively, focusing on locality-month cells instead of district-month cells. That is, Tables 7 and 8 are based on more refined micro-level data. The data set that focuses on localities is more detailed and hence the estimation is more precise than when using district-level data. Once we introduce locality fixed effects, however, the estimates rely only on the 43 localities in which least one suicide terrorist originated (out of 683 localities). Hence, by comparing the results from both district-month and locality-month aggregations, we make sure that the results are not unduly affected by the elimination from the sample of localities in which suicide attacks did not originate. 
We see a similar pattern in Tables 7 and 8 to the one found using data at the district level. That is, punitive house demolitions are shown to have a significant deterrent effect on suicide terrorists also when using data at the locality level. Remarkably, even the point estimates are of almost the same magnitude as those in Tables 5 and 6 . While measured at the locality level, a one standard deviation increase in punitive house demolitions causes a decrease of 14.9 percent on the odds of that a suicide terrorist originated from that locality within a month of the demolitions. This effect is higher than the one observed when data is aggregated at the district level (11.7 percent). As we show in subsection 5.4 below, the difference is explained by the spatial dissipation of the deterrent effect of punitive house demolitions.

In sum, we observe that punitive house demolitions have an immediate deterrent effect on suicide terrorism. This effect is robust to different specifications and for different measures of punitive house demolitions. In additional analysis presented in the Appendix we show that the effects of punitive house demolitions are qualitatively and quantitatively the same if we use a Negative Binomial model instead of a Poisson model (Table A.1). The deterrent effect of house demolitions on suicide terrorism is even larger when we eliminate from the sample the first year of the second Intifada, in which the IDF did not conduct punitive house demolitions (see Table A.2).

\subsection{Dynamic Effects of Punitive House Demolitions}

The previous section established that punitive house demolitions led to an immediate decline in suicide terrorism - within one month after the demolition. This section examines the persistency of the deterrent effect of house demolitions. We study the persistency of house demolitions over six months using a series of six Poisson regressions. That is, for each of the four available measures for house demolitions we use the specification in Column 5 of Table 5, except that each regression uses a different lag of house demolitions, which varies from one to six months. Figure 2 presents the estimated coefficients as well as 90 percent confidence bands.

The figure shows that the effect of punitive house demolitions, though significant a month after their occurrence, fades away over time. That is, the pattern of coefficients consistently shows for the four measures a negative and significant effect of house demolitions within a one-month lag and an almost monotonic convergence to zero for higher-order lags. Note also that the effect of punitive house demolitions is not statistically different from zero from a lag 
of two months and onward, indicating that the deterrent effect of house demolitions basically disappears after one month of their occurrence. ${ }^{13}$

One concern that arises from the findings in Figure 2 is that the short-lived effect of house demolitions is in fact caused by other counterterrorism measures that the IDF imposes on the terrorists' localities of origin after suicide attacks. For example, after a suicide attack the IDF may choose not only to demolish the house of the perpetrator but also to impose curfews, closures, and roadblocks while also increasing military presence in the area. Although we are able to control for curfews and Israeli-induced Palestinian fatalities, we do not have information on all other possible counterterrorism measures.

The analysis in Table 9 directly addresses the concern that confounding factors prevalent in the aftermath of a terror attack are behind the observed impact of punitive house demolitions on suicide terrorism. In this analysis, we eliminate from the data set all locality-month cells in which the IDF demolishes a house within a month of a suicide attack in direct retaliation for the attack. $^{14}$

The results of this analysis show that the significant negative effect of house demolitions on the number of suicide terrorists is not caused exclusively by immediate house demolitions after a terror attack. The estimated coefficients are statistically significant and only slightly lower in magnitude when compared to the coefficients estimated using the universe of suicide terrorists (Tables 7 and 8).

An alternative concern is that strategic considerations of terror cells may cause a decrease in suicide terrorism after a suicide attack. For example, the dynamics of suicide terrorism may be such that a terror cell imposes a period of relative calm, a strategy of "laying low," after a successful terror attack. Table 10 adds to the regressions the number of contemporaneous suicide attacks as an additional control variable to address this issue directly.

The results show that recent suicide terror attacks do not systematically affect future attacks. The coefficients on contemporaneous suicide attacks are not consistently significant across different specifications, and they even change sign when we control for other measures of

\footnotetext{
${ }^{13}$ This is consistent with the results of Jaeger et al. (2008). They found that Israeli-induced Palestinian fatalities radicalize the preferences of the Palestinian population within one month of their occurrence but that the effect dissipates within three months.

14 This occurred after 20 suicide attacks, with 17 cases in which the suicide terrorist's house was demolished within four days of the attack.
} 
counterterrorism. Importantly, however, the coefficients on house demolitions remain highly statistically significant and of the same magnitude as those estimated in Tables 5 and 6 . Hence, the message that emerges from Tables 9 and 10 and Figure 2 is that punitive house demolitions have a significant, albeit short-lived, negative impact on the number of suicide terrorists.

\subsection{Geographic Effects of Punitive House Demolitions}

In this section we analyze the geographic dispersion of the effect of punitive house demolitions on suicide terrorism. To that end, we study whether house demolitions in a neighboring district have an effect on local suicide terrorism. That is, we add to the specifications in Columns 6 and 7 of Table 5 an additional covariate with the number of punitive house demolitions in the rest of the districts in the same region. ${ }^{15}$

We find that the effects of house demolitions dissipate not only over time but also across geographic distance (Table 11). Accordingly, the effects of local punitive house demolitions on the number of local suicide terrorists are still negative and statistically significant. However, punitive house demolitions in other districts in the same region do not have a significant impact on the number of suicide terrorists.

\subsection{The Effects of Precautionary House Demolitions}

Here we study the effects of precautionary house demolitions on suicide terrorism. As mentioned in section 2, precautionary house demolitions refer to houses demolished in "clearing operations" intended to meet military needs. For houses demolished for punitive reasons, the IDF directly links the owner and/or occupant of the house to terror activity against Israel. That is, there is a direct link between an individual's action and the resulting punishment. In contrast, for houses demolished for precautionary reasons, the IDF does not claim an existing connection between the house occupant and terror activity. Hence, there is no connection between the individual's actions and the resulting demolition of the house. In fact, the main determinant of precautionary house demolitions is whether the house is located near the Egyptian or Israeli borders or surrounding an Israeli settlement or roads used by settlers. Following Kalyvas's

\footnotetext{
${ }^{15}$ We use the standard division of the 16 districts under the Palestinian Authority into West Bank and Gaza Strip. Accordingly, there are 11 districts in the West Bank (including East Jerusalem) and 5 districts in the Gaza Strip (see Figure 1).
} 
(2006) classification of types of violence, we view punitive house demolitions as a form of selective violence and precautionary house demolitions as a form of indiscriminate violence.

We test the effectiveness of precautionary house demolitions in Table 12. The models estimated include, in addition to precautionary house demolitions, the same controls used in Column 7 in Table $5 .{ }^{16}$ The table shows results with the data aggregated at the district and at the locality level. In addition, we present results both for the entire sample and excluding Rafah from the sample since Rafah is a clear outlier during this period. ${ }^{17}$

Interestingly, the results show that precautionary demolitions have a positive effect on the number of suicide terrorists. The estimated coefficients are statistically significant (when excluding Rafah from the sample) and of an important magnitude. The estimated rate ratio implies that the marginal precautionary house demolition increases the number of suicide terrorists originating from a district in the following month by a factor of 1.051 . This effect implies that a standard deviation increase in the number of precautionary house demolitions (which is equal to 7.99) causes an increase of 48.7 percent on the number of suicide terrorists originating from an average district-month cell.

These results provide strong support to the hypothesis that indiscriminate violence is counterproductive because it creates new grievances. ${ }^{18}$ As argued by Rosendorff and Sandler (2004) and Bueno de Mesquita and Dickson (2007) in related studies of terrorism, and by Kalyvas (2006) in his comprehensive study on the use of violence in civil wars, indiscriminate violence against civilians increases popular support for terrorist and insurgent groups. Terrorists and insurgents usually translate this increase into bigger cadres and increased violence against their political opponents.

\footnotetext{
${ }^{16}$ Given that the data on precautionary house demolitions are available only for the years 2004 and 2005 , we do not have enough within-district or within-locality variation for this type of demolition. Consequently, the regressions do not converge when we include district- or locality-specific linear time trends.

${ }^{17}$ See related discussion in section 3.

${ }^{18}$ See Condra and Shapiro (2010) for additional empirical support to this result based on an analysis of violence in Iraq between 2004 and 2008. Note, however, that Lyall (2009) finds that the use of indiscriminate violence in Chechnya by the Russian army caused a significant decrease in insurgents' attacks.
} 


\section{Conclusions}

This paper presents the first systematic examination of the effectiveness of house demolitions using a novel micro-level data set. Our analysis shows that punitive house demolitions, a selective policy of counterterrorism, lead to an immediate decrease in the number of suicide terrorists. This effect dissipates over time and space. In contrast to punitive house demolitions, precautionary house demolitions, which can be likened to an indiscriminate policy of counterterrorism, lead to a significance increase in the number of suicide terror attacks against Israeli citizens.

While we find that punitive house demolitions are an effective tool to deter suicide terrorism, it may not be an efficient policy because it may cause some undesirable consequences. For example, punitive house demolitions may lead to an increase in other types of terror attacks or bring about animosity from the international community against Israel. That said, by showing which types of demolitions deter terrorists and which promote more terrorism, we shed more light on the desirability of house demolitions and their effectiveness as a counter-suicideterrorism tool.

\section{References}

Alon, Gideon. 2002. "Ben Eliezer, 'There Are Testimonies That the Demolition of Terrorist's Houses Deters."' Ha'aretz, August 12.

Baliga, Sandeep, and Tomas Sjöström. 2010. "The Strategy of Manipulating Conflict." Unpublished manuscript, Northwestern University.

Becker, Gary S., and Yona Rubinstein. 2008. "Fear and the Response to Terrorism: An Economic Analysis.” Unpublished manuscript, Brown University.

Benmelech, Efraim, and Claude Berrebi. 2007. "Human Capital and the Productivity of Suicide Bombers." Journal of Economic Perspectives 21 (3): 223-238.

Benmelech, Efraim, Claude Berrebi, and Esteban F. Klor. 2010. "The Economic Cost of Harboring Terrorism." Journal of Conflict Resolution 54 (2): 331-353.

Benmelech, Efraim, Claude Berrebi, and Esteban F. Klor. 2009. "Economic Conditions and the Quality of Suicide Terrorism.” Unpublished manuscript, Harvard University. 
Berman, Eli. 2009. Radical, Religious, and Violent: The New Economics of Terrorism. Cambridge, MA: MIT Press.

Berman, Eli, and David D. Laitin. 2008. "Religion, Terrorism and Public Goods: Testing the Club Model." Journal of Public Economics 92 (10-11): 1942-1967.

Braverman, Irus. 2007. "Powers of Illegality: House Demolitions and Resistance in East Jerusalem." Law and Social Inquiry 32 (2): 333-372.

Bueno de Mesquita, Ethan. 2007. "Politics and the Suboptimal Provision of Counterterror." International Organization 61 (1): 9-36.

Bueno de Mesquita, Ethan, and Eric S. Dickson. 2007. "The Propaganda of the Deed: Terrorism, Counterterrorism, and Mobilization.” American Journal of Political Science 51 (2): 364 381.

Condra, Luke, and Jacob Shapiro. 2010. "Who Takes the Blame? The Strategic Effects of Collateral Damage." Unpublished manuscript, Princeton University.

Darcy, Shane. 2003. Israeli's Punitive House Demolition Policy: Collective Punishment in Violation of International Law. West Bank, Palestine: Al-Haq.

Enders, Walter, and Todd Sandler. 1993. "The Effectiveness of Antiterrorism Policies: A VectorAutoregression-Intervention Analysis.” American Political Science Review 87 (4): 829 844.

Enders, Walter, and Todd Sandler. 2004. "What Do We Know about the Substitution Effect in Transnational Terrorism?” In Researching Terrorism: Trends, Achievements, Failures, ed. Andrew Silke, 119-137. Ilford, UK: Frank Cass.

Fearon, James D., and David D. Laitin. 2003. "Ethnicity, Insurgency, and Civil War." American Political Science Review 97 (1): 75-90.

Ganor, Boaz. 2005. The Counter-Terrorism Puzzle: A Guide for Decision Makers. New Brunswick, NJ: Transaction.

Gould, Eric, and Esteban F. Klor. 2010. “Does Terrorism Work?” Quarterly Journal of Economics, forthcoming.

Gould, Eric, and Guy Stecklov. 2009. "Terror and the Costs of Crime." Journal of Public Economics 93 (11-12): 1175-1188.

Harel, Amos, and Avi Issacharoff. 2004. The Seventh War. Tel Aviv: Yediot Ahronot Books. [In Hebrew] 
Human Rights Watch. 2004. Razing Rafah: Mass Home Demolitions in the Gaza Strip. New York: Human Rights Watch.

Jaeger, David A., and M. Daniele Paserman. 2006. "Israel, the Palestinian Factions, and the Cycle of Violence." American Economic Review 96 (2): 45-49.

Jaeger, David A., and M. Daniele Paserman. 2008. “The Cycle of Violence? An Empirical Analysis of Fatalities in the Palestinian-Israeli Conflict." American Economic Review 98 (4): 1591-1604.

Kalyvas, Stahis. 2006. The Logic of Violence in Civil War. New York: Cambridge University Press.

Lyall, Jason. 2009. "Does Indiscriminate Violence Incite Insurgents Attacks? Evidence from Chechnya." Journal of Conflict Resolution 53 (3): 331-362.

Nabot, Suzie. 2003. “The Supreme Court of Israel and the War against Terror.” European Public Law 9 (3): 323-333.

Powell, Robert. 2007a. "Defending against Terrorist Attacks with Limited Resources." American Political Science Review 101 (3): 527-541.

Powell, Robert. 2007b. “Allocating Defensive Resources with Private Information about Vulnerability." American Political Science Review 101 (4): 799-809.

Rosendorff, Peter, and Todd Sandler. 2004. "Too Much of a Good Thing? The Proactive Response Dilemma.” Journal of Conflict Resolution 48 (4): 657-671.

Shnayderman, Ronen. 2004. Through No Fault of Their Own: Punitive House Demolitions during the Al-Aqsa Intifada. B'Tselem: The Israeli Information Center for Human Rights in the Occupied Territories.

Siqueira, Kevin, and Todd Sandler. 2006. "Terrorists versus the Government: Strategic Interaction, Support, and Sponsorship.” Journal of Conflict Resolution 50 (6): 878-898. 
Figure 1. Suicide terrorists and house demolitions, October 2000-December 2005

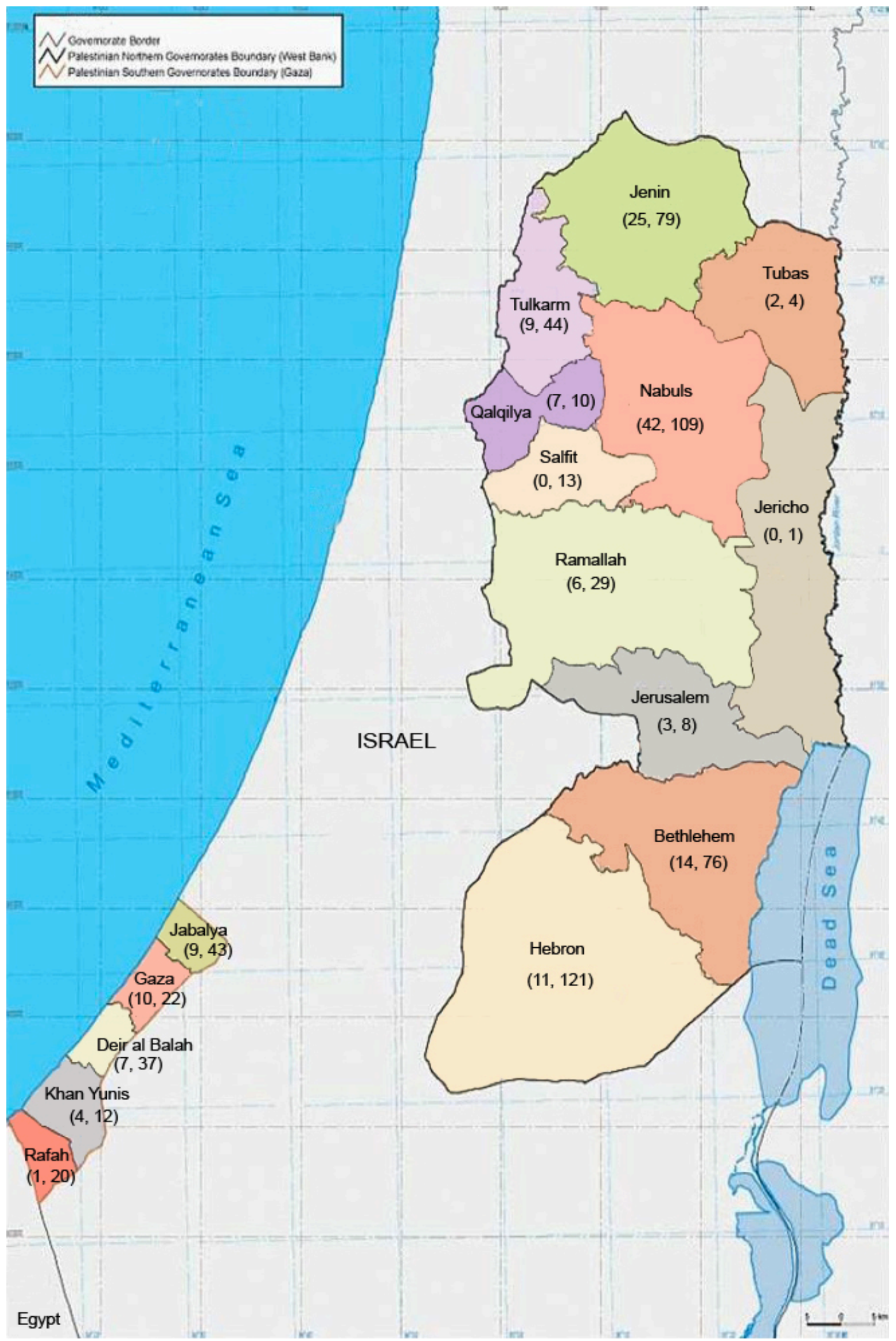


Figure 2. The dynamic effects of punitive demolitions on the number of suicide attacks $(95 \% \mathrm{CI}$ in shaded area)
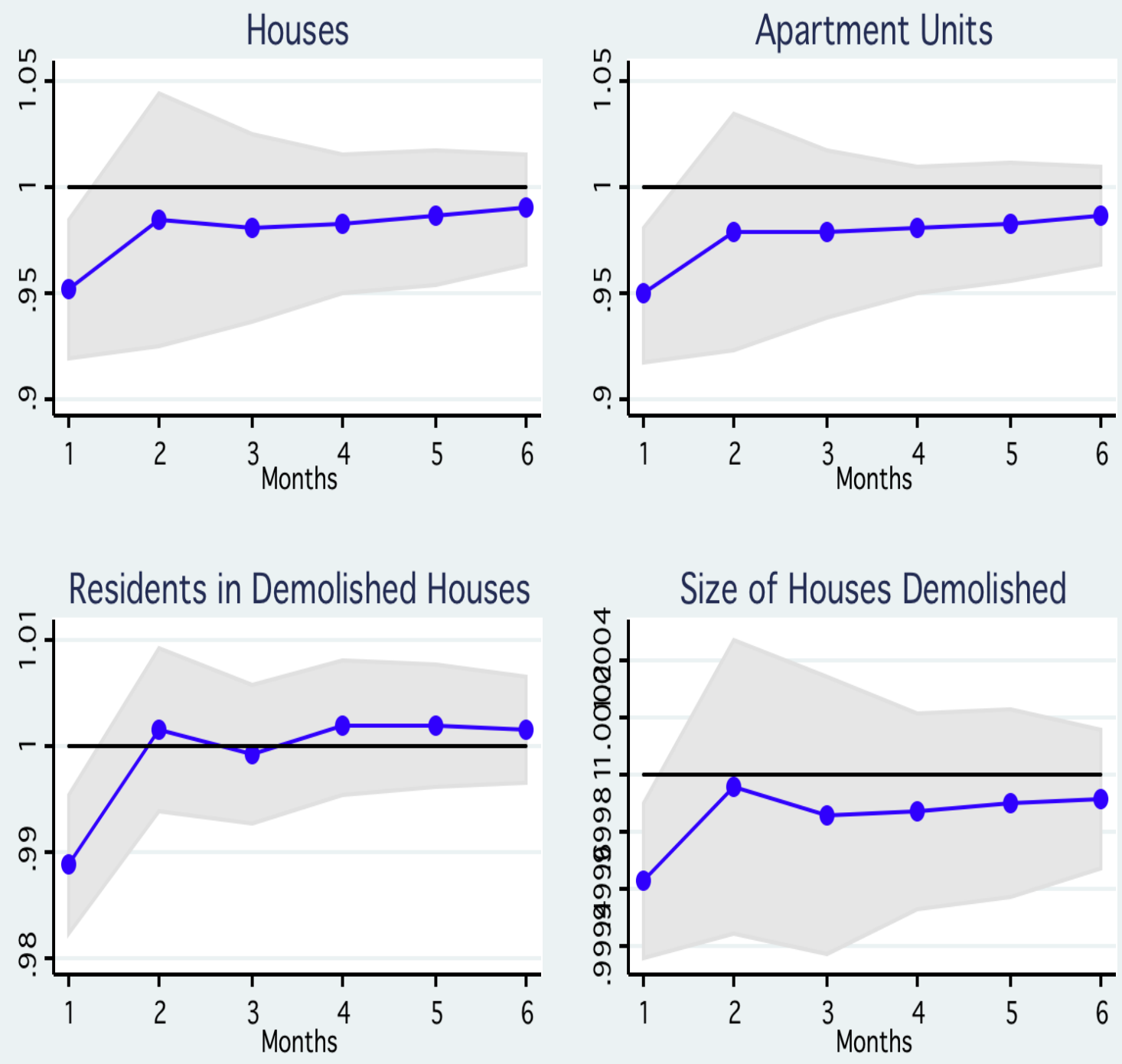
Table 1

Suicide Terror Attacks, Palestinian Fatalities, and House Demolitions by Year

\begin{tabular}{|c|c|c|c|c|c|c|}
\hline & 2000 & 2001 & 2002 & 2003 & 2004 & 2005 \\
\hline \multicolumn{7}{|l|}{ House Demolitions } \\
\hline Punitive & 0 & 6 & 235 & 218 & 167 & 2 \\
\hline Precautionary & - & - & - & - & 1,156 & 16 \\
\hline \multicolumn{7}{|l|}{ Units Demolished } \\
\hline Punitive & 0 & 7 & 246 & 218 & 174 & 2 \\
\hline Precautionary & - & - & - & - & 1,404 & 17 \\
\hline \multicolumn{7}{|c|}{ Number of Residents in Demolished Houses } \\
\hline Punitive & 0 & 24 & 1,371 & 1,766 & 895 & 17 \\
\hline Precautionary & - & - & - & - & 10,704 & 74 \\
\hline \multicolumn{7}{|c|}{ Size of Houses Demolished (in square meters) } \\
\hline Punitive & 0 & 1,010 & 26,313 & 32,219 & 23,868 & 400 \\
\hline Precautionary & - & - & - & - & 216,278 & 1,972 \\
\hline Suicide Terrorists & 3 & 32 & 59 & 28 & 15 & 13 \\
\hline Palestinian-Induced Israeli Fatalities & 41 & 191 & 421 & 185 & 108 & 50 \\
\hline Israeli-Induced Palestinian Fatalities & 280 & 462 & 1,000 & 580 & 825 & 190 \\
\hline
\end{tabular}

Notes: Entries reflect the total number of suicide terrorists, Israeli-induced Palestinian fatalities, and house demolitions by year. The year 2000 covers only the months of October, November, and December. The data on suicide terrorists come from Israeli Security Agency reports. The data for the rest of the variables come from B'tselem. 
Table 2

Summary Statistics on Localities number of Suicide Terrorists, Palestinian Fatalities, and House Demolitions (using all 683 localities in the Palestinian Census of 1997)

\begin{tabular}{|c|c|c|c|c|}
\hline & Mean & $\begin{array}{l}\text { Standard } \\
\text { Deviation }\end{array}$ & Minimum & Maximum \\
\hline Suicide Terrorists Originating from Locality & 0.218 & 1.57 & 0 & 30 \\
\hline Israeli-Induced Palestinian Fatalities & 4.886 & 29.97 & 0 & 490 \\
\hline \multicolumn{5}{|l|}{ House Demolitions } \\
\hline Punitive & 0.919 & 4.55 & 0 & 88 \\
\hline Precautionary & 1.716 & 26.59 & 0 & 605 \\
\hline \multicolumn{5}{|l|}{ Units Demolished } \\
\hline Punitive & 0.944 & 4.59 & 0 & 86 \\
\hline Precautionary & 2.081 & 32.14 & 0 & 756 \\
\hline \multicolumn{5}{|l|}{ Number of Residents in Demolished Houses } \\
\hline Punitive & 5.96 & 34.54 & 0 & 765 \\
\hline Precautionary & 15.78 & 264.11 & 0 & 6,325 \\
\hline \multicolumn{5}{|l|}{ Size of Houses Demolished (in square meters) } \\
\hline Punitive & 122.71 & 565 & 0 & 9,755 \\
\hline Precautionary & 319.55 & 4,969 & 0 & 117,156 \\
\hline
\end{tabular}

Notes: Entries reflect the respective statistic for the total variable of interest for each locality between October 2000 and December 2005. The data on suicide terrorists come from Israeli Security Agency reports. The data for the rest of the variables come from Btselem. All the calculations are based on the extant 683 Palestinian localities surveyed in the 1997 Palestinian Census conducted by the Palestinian Central Bureau of Statistics. 
Table 3

Summary Statistics on Localities' Number of Suicide Terrorists, Palestinian Fatalities, and House Demolitions (using only the 43 localities in which a suicide terrorist originated)

\begin{tabular}{|c|c|c|c|c|c|}
\hline & Mean & $\begin{array}{l}\text { Standard } \\
\text { Deviation }\end{array}$ & Median & Minimum & Maximum \\
\hline Suicide Terrorists Originating from Locality & 3.47 & 5.329 & 2.0 & 1 & 30 \\
\hline Israeli-Induced Palestinian Fatalities & 63.5 & 103.44 & 14 & 0 & 490 \\
\hline \multicolumn{6}{|l|}{ House Demolitions } \\
\hline Punitive & 10.63 & 14.55 & 6 & 0 & 88 \\
\hline Precautionary & 25.58 & 103.82 & 0 & 0 & 605 \\
\hline \multicolumn{6}{|l|}{ Units Demolished } \\
\hline Punitive & 11.00 & 14.52 & 6 & 0 & 88 \\
\hline Precautionary & 31.09 & 125.52 & 0 & 0 & 756 \\
\hline \multicolumn{6}{|l|}{ Number of Residents in Demolished Houses } \\
\hline Punitive & 69.93 & 118.9 & 36 & 0 & 765 \\
\hline Precautionary & 239.53 & 1,037 & 0 & 0 & 6,325 \\
\hline \multicolumn{6}{|l|}{ Size of Houses Demolished (in square meters) } \\
\hline Punitive & 1,360 & 1,744 & 750 & 0 & 9,755 \\
\hline Precautionary & 4,757 & 19,401 & 0 & 0 & 117,156 \\
\hline
\end{tabular}

Notes: Entries reflect the respective statistic for the total variable of interest for each locality between October 2000 and December 2005 . The data on suicide terrorists come from Israeli Security Agency reports. The data for the rest of the variables come from B'tselem. 
Table 4

Summary Statistics on Curfews, Economic, and Demographic Characteristics

\begin{tabular}{lccccc}
\hline & Mean & $\begin{array}{c}\text { Standard } \\
\text { Deviation }\end{array}$ & Median & Minimum & Maximum \\
\hline Age & 33.6 & 0.840 & 33.9 & 32.2 & 34.7 \\
Share of Males in Population & 0.502 & 0.008 & 0.501 & 0.478 & 0.512 \\
Married Population & 0.569 & 0.023 & 0.561 & 0.532 & 0.609 \\
Years of Schooling & 9.18 & 0.398 & 9.20 & 8.26 & 9.83 \\
Unemployment & 0.106 & 0.024 & 0.113 & 0.056 & 0.153 \\
Share of Population Working in Israel & 0.045 & 0.029 & 0.044 & 0.013 & 0.118 \\
Days with Curfews & 1.341 & 1.712 & 0.057 & 0 & 4.596 \\
\end{tabular}

Notes: Entries reflect the respective statistic for the districts' averages between October 2000 and December 2005 for all variables except curfews (available only from May 2002 onward). The data on curfews come from the UN Office for the Coordination of Humanitarian Affairs. The data for the rest of the variables come from the Palestinian Labor Force Survey, conducted by the Palestinian Central Bureau of Statistics. 
Table 5

The Effect of Punitive House Demolitions on the Number of Suicide Attacks

(all data aggregated at the district level)

\begin{tabular}{|c|c|c|c|c|c|c|c|}
\hline Variable & (1) & (2) & (3) & (4) & (5) & (6) & (7) \\
\hline Punitive House Demolitions & $\begin{array}{c}0.0633 * \\
{[0.0334]}\end{array}$ & $\begin{array}{c}0.0281 \\
{[0.0303]}\end{array}$ & $\begin{array}{l}-0.0186 \\
{[0.0264]}\end{array}$ & $\begin{array}{l}-0.0607 * * * \\
{[0.0181]}\end{array}$ & $\begin{array}{l}-0.0609 * * * \\
{[0.0203]}\end{array}$ & $\begin{array}{l}-0.0527 * * * \\
{[0.0186]}\end{array}$ & $\begin{array}{l}-0.0492 * * \\
{[0.0230]}\end{array}$ \\
\hline \multicolumn{8}{|c|}{ Districts' Economic and Demographic Characteristics } \\
\hline - Unemployment & & & & & $\begin{array}{c}-2.0040 \\
{[4.075]}\end{array}$ & $\begin{array}{c}-8.4461 * \\
{[4.723]}\end{array}$ & $\begin{array}{c}-8.0973 \\
{[7.199]}\end{array}$ \\
\hline - Percentage Employed in Israel & & & & & $\begin{array}{l}1.5980 \\
{[3.275]}\end{array}$ & $\begin{array}{l}0.8483 \\
{[3.263]}\end{array}$ & $\begin{array}{l}-11.655 \\
{[11.218]}\end{array}$ \\
\hline - Years of Schooling & & & & & $\begin{array}{l}-0.2781 \\
{[0.4931]}\end{array}$ & $\begin{array}{c}0.2201 \\
{[0.6507]}\end{array}$ & $\begin{array}{l}-0.2468 \\
{[0.9121]}\end{array}$ \\
\hline - Age & & & & & $\begin{array}{l}0.2900 * \\
{[0.1647]}\end{array}$ & $\begin{array}{l}0.5115 * * * \\
{[0.1452]}\end{array}$ & $\begin{array}{c}0.0323 \\
{[0.3752]}\end{array}$ \\
\hline - Married & & & & & $\begin{array}{c}-0.3319 \\
{[6.746]}\end{array}$ & $\begin{array}{c}-2.5222 \\
{[7.998]}\end{array}$ & $\begin{array}{c}1.7027 \\
{[10.568]}\end{array}$ \\
\hline - Male & & & & & $\begin{array}{c}11.070 \\
{[12.806]}\end{array}$ & $\begin{array}{c}8.744 \\
{[11.346]}\end{array}$ & $\begin{array}{l}-7.4672 \\
{[11.308]}\end{array}$ \\
\hline \multicolumn{8}{|l|}{ Other-Security Related Variables } \\
\hline - Palestinian Fatalities & & & & & & $\begin{array}{c}0.010 * \\
{[0.006]}\end{array}$ & $\begin{array}{l}-0.0425 \\
{[0.0472]}\end{array}$ \\
\hline - Days with Curfews & & & & & & & $\begin{array}{l}0.0603 * * \\
{[0.0281]}\end{array}$ \\
\hline District Fixed Effects & No & No & Yes & Yes & Yes & Yes & Yes \\
\hline Year Fixed Effects & No & Yes & No & Yes & Yes & Yes & Yes \\
\hline District-Specific Linear Time Trends & No & No & No & No & No & Yes & No \\
\hline Number of Observations & 1,008 & 1,008 & 1,008 & 1,008 & 1,008 & 1,008 & 704 \\
\hline
\end{tabular}

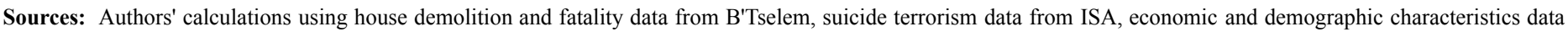
from the Palestinian Labor Force Survey, and curfews data from UN OCHA. The data set covers the period October 2000 to December 2005.

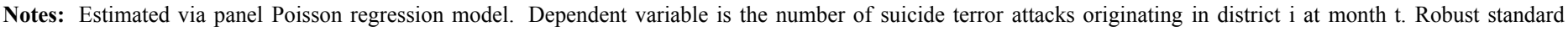

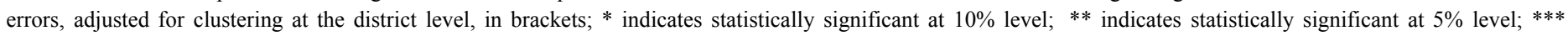
indicates statistically significant at 1\% level. 
Table 6

The Effect Punitive House Demolitions on the Number of Suicide Attacks

(all data aggregated at the district level)

\begin{tabular}{lcccc}
\hline Variable & $(1)$ & $(2)$ & $(3)$ & $(4)$ \\
\hline Number of Apartment Units Demolished & $-0.0632 * * *$ & $-0.0640 * * *$ & $-0.0586 * * *$ & $-0.0539 * * *$ \\
& {$[0.0173]$} & {$[0.0194]$} & {$[0.0176]$} & {$[0.0207]$} \\
\hline Number of Residents in Demolished Houses & & & & \\
& $-0.0131 * * *$ & $-0.0135 * * *$ & $-0.0130 * * *$ & $-0.0115 * * *$ \\
& {$[0.0039]$} & {$[0.0043]$} & {$[0.0043]$} & {$[0.0042]$} \\
\hline Size of House Demolished (hundred square meters) & & & & \\
& $-0.0463 * * *$ & $-0.0467 * * *$ & $-0.0445 * * *$ & $-0.0410 * *$ \\
& {$[0.0153]$} & {$[0.0167]$} & {$[0.0175]$} & {$[0.0204]$} \\
\hline District Fixed Effects & & & Yes & Yes \\
Year Fixed Effects & Yes & Yes & Yes & Yes \\
Economic and Demographic Controls & Yes & Yes & Yes & Yes \\
Other Proxies for Counter-terrorism & No & Yes & Yes & Yes \\
District-Specific Linear Time Trends & No & No & No & 1,008 \\
Number of Observations & No & 1,008 & No & 704 \\
\hline
\end{tabular}

Sources: Authors' calculations using house demolition and fatality data from B'Tselem, suicide terrorism data from ISA, economic and demographic characteristics data from the Palestinian Labor Force Survey, and curfews data from UN OCHA. The data set covers the period October 2000 to December 2005.

Notes: Each column in each panel presents the results of a different regression estimated via panel Poisson regression model. Dependent variable is the suicide terror attacks originating in district $i$ at month $t$. The economic and demographic controls are the same ones used in specifications 2, 3, 5, and 6 in Table 5. Other proxies for counterterrorism are Israeli-induced Palestinian fatalities and curfews, as used in specifications 3 and 6 in Table 5. Robust standard errors, adjusted for clustering at the district level, in brackets; * indicates statistically significant at $10 \%$ level; ** indicates statistically significant at $5 \%$ level; *** indicates statistically significant at $1 \%$ level. 
Table 7

The Effect of Punitive House Demolitions on the Number of Suicide Attacks

\begin{tabular}{|c|c|c|c|c|c|c|c|}
\hline Variable & (1) & (2) & (3) & (4) & (5) & (6) & (7) \\
\hline Punitive House Demolitions & $\begin{array}{l}-0.0136 \\
{[0.0438]}\end{array}$ & $\begin{array}{l}-0.0505 \\
{[0.0396]}\end{array}$ & $\begin{array}{l}-0.0213 \\
{[0.0294]}\end{array}$ & $\begin{array}{l}-0.0608 * * * \\
{[0.0239]}\end{array}$ & $\begin{array}{l}-0.0609 * * * \\
{[0.0254]}\end{array}$ & $\begin{array}{l}-0.0550 * * \\
{[0.0248]}\end{array}$ & $\begin{array}{l}-0.0560 * * \\
{[0.0284]}\end{array}$ \\
\hline \multicolumn{8}{|c|}{ Districts' Economic and Demographic Characteristics } \\
\hline - Unemployment & & & & & $\begin{array}{c}-1.9330 \\
{[3.598]}\end{array}$ & $\begin{array}{c}-8.1658 * \\
{[4.414]}\end{array}$ & $\begin{array}{c}-8.4613 \\
{[7.035]}\end{array}$ \\
\hline - Percentage Employed in Israel & & & & & $\begin{array}{l}1.6018 \\
{[5.288]}\end{array}$ & $\begin{array}{c}0.556 \\
{[5.241]}\end{array}$ & $\begin{array}{l}-11.610 \\
{[11.982]}\end{array}$ \\
\hline - Years of Schooling & & & & & $\begin{array}{l}-0.2519 \\
{[0.4957]}\end{array}$ & $\begin{array}{c}0.1971 \\
{[0.6212]}\end{array}$ & $\begin{array}{l}-0.1298 \\
{[0.8685]}\end{array}$ \\
\hline - Age & & & & & $\begin{array}{c}0.2953 * \\
{[0.1720]}\end{array}$ & $\begin{array}{l}0.5459 * * * \\
{[0.1906]}\end{array}$ & $\begin{array}{c}0.0216 \\
{[0.3906]}\end{array}$ \\
\hline - Married & & & & & $\begin{array}{c}-0.1299 \\
{[5.572]}\end{array}$ & $\begin{array}{c}-1.9841 \\
{[6.260]}\end{array}$ & $\begin{array}{l}2.1108 \\
{[8.029]}\end{array}$ \\
\hline - Male & & & & & $\begin{array}{l}11.116 \\
{[9.451]}\end{array}$ & $\begin{array}{l}8.3061 \\
{[9.283]}\end{array}$ & $\begin{array}{l}-7.9122 \\
{[10.718]}\end{array}$ \\
\hline \multicolumn{8}{|l|}{ Other Security-Related Variables } \\
\hline - Palestinian Fatalities & & & & & & $\begin{array}{c}0.0077 \\
{[0.0119]}\end{array}$ & $\begin{array}{l}-0.0361 \\
{[0.0824]}\end{array}$ \\
\hline - Days with Curfews & & & & & & & $\begin{array}{l}0.0592 * * \\
{[0.0269]}\end{array}$ \\
\hline Locality Fixed Effects & No & No & Yes & Yes & Yes & Yes & Yes \\
\hline Year Fixed Effects & No & Yes & No & Yes & Yes & Yes & Yes \\
\hline District-Specific Linear Time Trends & No & No & No & No & No & Yes & No \\
\hline Number of Observations & 42,346 & 42,346 & 2,666 & 2,666 & 2,666 & 2,666 & 1,849 \\
\hline
\end{tabular}

Sources: Authors' calculations using house demolition and fatality data from B'Tselem, suicide terrorism data from ISA, economic and demographic characteristics data from the Palestinian Labor Force Survey, and curfews data from UN OCHA. The data set covers the period October 2000 to December 2005.

Notes: Estimated via panel Poisson regression model. Dependent variable is the number of suicide terror attacks originating in district $i$ at month t. Robust standard errors, adjusted for clustering at the district level, in brackets; * indicates statistically significant at $10 \%$ level; ** indicates statistically significant at $5 \%$ level; *** indicates statistically significant at $1 \%$ level. 
Table 8

The Effect of Punitive House Demolitions on the Number of Suicide Attacks

\begin{tabular}{|c|c|c|c|c|}
\hline Variable & $(1)$ & (2) & (3) & (4) \\
\hline Number of Apartment Units Demolished & $\begin{array}{l}-0.0632 * * * \\
{[0.0238]}\end{array}$ & $\begin{array}{l}-0.0640 * * * \\
{[0.0254]}\end{array}$ & $\begin{array}{l}-0.0585 * * * \\
{[0.0247]}\end{array}$ & $\begin{array}{l}-0.0604 * * \\
{[0.0292]}\end{array}$ \\
\hline Number of Residents in Demolished Houses & $\begin{array}{l}-0.0132 * * * \\
{[0.0039]}\end{array}$ & $\begin{array}{l}-0.0135 * * * \\
{[0.0042]}\end{array}$ & $\begin{array}{l}-0.0129 * * * \\
{[0.0042]}\end{array}$ & $\begin{array}{l}-0.0126 * * * \\
{[0.0047]}\end{array}$ \\
\hline Size of House Demolished (hundred square meters) & $\begin{array}{l}-0.0464 * * * \\
{[0.0198]}\end{array}$ & $\begin{array}{l}-0.0467 * * \\
{[0.0208]}\end{array}$ & $\begin{array}{l}-0.0445 * * \\
{[0.0217]}\end{array}$ & $\begin{array}{l}-0.0465 * \\
{[0.0260]}\end{array}$ \\
\hline Locality Fixed Effects & Yes & Yes & Yes & Yes \\
\hline Year Fixed Effects & Yes & Yes & Yes & Yes \\
\hline Economic and Demographic Controls & No & Yes & Yes & Yes \\
\hline Other Proxies for Counter-terrorism & No & No & Yes & Yes \\
\hline District-Specific Linear Time Trends & No & No & Yes & No \\
\hline Number of Observations & 2,666 & 2,666 & 2,666 & 1,849 \\
\hline
\end{tabular}

Sources: Authors' calculations using house demolition and fatality data from B'Tselem, suicide terrorism data from ISA, economic and demographic characteristics data from the Palestinian Labor Force Survey, and curfews data from OCHA. The data set covers the period October 2000 to December 2005.

Notes: Each column in each panel presents the results of a different regression estimated via panel Poisson regression model. Dependent variable is the suicide terror attacks originating in district $i$ at month $t$. The economic and demographic controls are the same ones used in specifications 2, 3, 5, and 6 in Table 5. Other proxies for counterterrorism are Israeli-induced Palestinian fatalities and curfews, as used in specifications 3 and 6 in Table 5. Robust standard errors, adjusted for clustering at the district level, in brackets; * indicates statistically significant at $10 \%$ level; ** indicates statistically significant at $5 \%$ level; *** indicates statistically significant at $1 \%$ level. 
Table 9

The Effect of Punitive House Demolitions on the Number of Suicide Attacks

(excluding localities-month cells with suicide attacks and house demolitions)

\begin{tabular}{|c|c|c|c|c|}
\hline Variable & $(1)$ & $(2)$ & (3) & $(4)$ \\
\hline Number of Houses Demolished & $\begin{array}{l}-0.0563 * * \\
{[0.0248]}\end{array}$ & $\begin{array}{l}-0.0573 * * \\
{[0.0269]}\end{array}$ & $\begin{array}{l}-0.0495 * \\
{[0.0262]}\end{array}$ & $\begin{array}{l}-0.0528 * \\
{[0.0317]}\end{array}$ \\
\hline Number of Apartment Units Demolished & $\begin{array}{l}-0.0593 * * \\
{[0.0252]}\end{array}$ & $\begin{array}{l}-0.0609 * * \\
{[0.0274]}\end{array}$ & $\begin{array}{l}-0.0529 * * \\
{[0.0263]}\end{array}$ & $\begin{array}{l}-0.0574 * \\
{[0.0326]}\end{array}$ \\
\hline Number of Residents in Demolished Houses & $\begin{array}{l}-0.0122 * * * \\
{[0.0040]}\end{array}$ & $\begin{array}{l}-0.0126 \text { *** } \\
{[0.0043]}\end{array}$ & $\begin{array}{l}-0.0115 * * * \\
{[0.0044]}\end{array}$ & $\begin{array}{l}-0.0115 * * * \\
{[0.0047]}\end{array}$ \\
\hline Size of House Demolished (hundred square meters) & $\begin{array}{l}-0.0460 * * \\
{[0.0203]}\end{array}$ & $\begin{array}{l}-0.0468 * * \\
{[0.0219]}\end{array}$ & $\begin{array}{l}-0.0430 * \\
{[0.0224]}\end{array}$ & $\begin{array}{l}-0.0471 * \\
{[0.0272]}\end{array}$ \\
\hline Locality Fixed Effects & Yes & Yes & Yes & Yes \\
\hline Year Fixed Effects & Yes & Yes & Yes & Yes \\
\hline Economic and Demographic Controls & No & Yes & Yes & Yes \\
\hline Other Proxies for Counter-terrorism & No & No & No & Yes \\
\hline District Specific Linear Time Trends & No & No & Yes & No \\
\hline Number of Observations & 2,646 & 2,646 & 2,646 & 1,830 \\
\hline
\end{tabular}

Sources: Authors' calculations using house demolition and fatality data from B'Tselem, suicide terrorism data from ISA, economic and demographic characteristics data from the Palestinian Labor Force Survey, and curfews data from UN OCHA. The data set covers the period October 2000 to December 2005.

Notes: Each column in each panel presents the results of a different regression estimated via panel Poisson regression model. Dependent variable is the suicide terror attacks originating in district $i$ at month $t$. The economic and demographic controls are the same ones used in specifications 2, 3, 5, and 6 in Table 5. Other proxies for counterterrorism are Israeli-induced Palestinian fatalities and curfews, as used in specifications 3 and 6 in Table 5. Robust standard errors, adjusted for clustering at the district level, in brackets; * indicates statistically significant at $10 \%$ level; ** indicates statistically significant at $5 \%$ level; *** indicates statistically significant at $1 \%$ level. 
Table 10

The Effect of Punitive House Demolitions on the Number of Suicide Attacks, Controlling for Terror Dynamics

\begin{tabular}{|c|c|c|c|c|}
\hline Variable & $(1)$ & $(2)$ & $(3)$ & $(4)$ \\
\hline Number of Houses Demolished & $\begin{array}{l}-0.0582 * * * \\
{[0.0173]}\end{array}$ & $\begin{array}{l}-0.0603 * * * \\
{[0.0199]}\end{array}$ & $\begin{array}{l}-0.0525 * * * \\
{[0.0186]}\end{array}$ & $\begin{array}{l}-0.0493 * * \\
{[0.0228]}\end{array}$ \\
\hline Contemporaneous Suicide Attacks & $\begin{array}{c}0.1494 \\
{[0.0917]}\end{array}$ & $\begin{array}{c}0.1393 * \\
{[0.0826]}\end{array}$ & $\begin{array}{c}0.0691 \\
{[0.0645]}\end{array}$ & $\begin{array}{l}-0.0215 \\
{[0.1300]}\end{array}$ \\
\hline Number of Apartment Units Demolished & $\begin{array}{l}-0.0607 * * * \\
{[0.0163]}\end{array}$ & $\begin{array}{l}-0.0634 * * * \\
{[0.0189]}\end{array}$ & $\begin{array}{l}-0.0585 * * * \\
{[0.0175]}\end{array}$ & $\begin{array}{l}-0.0540 * * * \\
{[0.0204]}\end{array}$ \\
\hline Contemporaneous Suicide Attacks & $\begin{array}{c}0.1493 \\
{[0.0925]}\end{array}$ & $\begin{array}{c}0.1396 * \\
{[0.0830]}\end{array}$ & $\begin{array}{c}0.0591 \\
{[0.0732]}\end{array}$ & $\begin{array}{l}-0.0210 \\
{[0.1326]}\end{array}$ \\
\hline Number of Residents in Demolished Houses & $\begin{array}{l}-0.0127 * * * \\
{[0.0037]}\end{array}$ & $\begin{array}{l}-0.0135 * * * \\
{[0.0041]}\end{array}$ & $\begin{array}{l}-0.0130 * * * \\
{[0.0042]}\end{array}$ & $\begin{array}{l}-0.0115 * * * \\
{[0.0042]}\end{array}$ \\
\hline Contemporaneous Suicide Attacks & $\begin{array}{c}0.1467 \\
{[0.0940]}\end{array}$ & $\begin{array}{l}0.1391 * \\
{[0.0835]}\end{array}$ & $\begin{array}{c}0.0590 \\
{[0.0727]}\end{array}$ & $\begin{array}{l}-0.0235 \\
{[0.1264]}\end{array}$ \\
\hline Size of House Demolished (hundred square meters) & $\begin{array}{l}-0.0443 * * * \\
{[0.0153]}\end{array}$ & $\begin{array}{l}-0.0462 * * * \\
{[0.0169]}\end{array}$ & $\begin{array}{l}-0.0444 * * * \\
{[0.0177]}\end{array}$ & $\begin{array}{l}-0.0410 * * \\
{[0.0202]}\end{array}$ \\
\hline Contemporaneous Suicide Attacks & $\begin{array}{c}0.1516 \\
{[0.0933]}\end{array}$ & $\begin{array}{c}0.1409 * \\
{[0.0846]}\end{array}$ & $\begin{array}{c}0.0596 \\
{[0.0754]}\end{array}$ & $\begin{array}{l}-0.0146 \\
{[0.1271]}\end{array}$ \\
\hline Locality Fixed Effects & Yes & Yes & Yes & Yes \\
\hline Year Fixed Effects & Yes & Yes & Yes & Yes \\
\hline Economic and Demographic Controls & No & Yes & Yes & Yes \\
\hline Other Proxies for Counter-terrorism & No & No & No & Yes \\
\hline District-Specific Linear Time Trends & No & No & Yes & No \\
\hline Number of Observations & 2,646 & 2,646 & 2,646 & 1,830 \\
\hline
\end{tabular}

Sources: Authors' calculations using house demolition and fatality data from B'Tselem, suicide terrorism data from ISA, economic and demographic characteristics data from the Palestinian Labor Force Survey, and curfews data from UN OCHA. The data set covers the period October 2000 to December 2005.

Notes: Each column in each panel presents the results of a different regression estimated via panel Poisson regression model. Dependent variable is the suicide terror attacks originating in district $\mathrm{i}$ at month $\mathrm{t}$. The economic and demographic controls are the same ones used in specifications 2, 3, 5, and 6 in Table 5. Other proxies for counterterrorism are Israeli-induced Palestinian fatalities and curfews, as used in specifications 3 and 6 in Table 5. Robust standard errors, adjusted for clustering at the district level, in brackets; * indicates statistically significant at $10 \%$ level; ** indicates statistically significant at 5\% level; *** indicates statistically significant at $1 \%$ level. 
Table 11

The Geographic Effect of Punitive Demolitions on the Number of Suicide Attacks

\begin{tabular}{|c|c|c|c|c|}
\hline Variable & $(1)$ & $(2)$ & (3) & (4) \\
\hline & \multicolumn{2}{|c|}{ Number of Houses Demolished } & \multicolumn{2}{|c|}{$\begin{array}{c}\text { Number of Apartment Units } \\
\text { Demolished }\end{array}$} \\
\hline - Demolitions in the District & $\begin{array}{l}-0.0413 * * \\
{[0.0187]}\end{array}$ & $\begin{array}{l}-0.0494 * \\
{[0.0260]}\end{array}$ & $\begin{array}{l}-0.0435 * * * \\
{[0.0179]}\end{array}$ & $\begin{array}{l}-0.0539 * * \\
{[0.0247]}\end{array}$ \\
\hline - Other Demolitions in the Region & $\begin{array}{l}-0.0177 \\
{[0.0165]}\end{array}$ & $\begin{array}{c}0.0009 \\
{[0.0194]}\end{array}$ & $\begin{array}{l}-0.0174 \\
{[0.0149]}\end{array}$ & $\begin{array}{l}0.00005 \\
{[0.0184]}\end{array}$ \\
\hline & \multicolumn{2}{|c|}{$\begin{array}{l}\text { Number of Residents in } \\
\text { Demolished Houses }\end{array}$} & \multicolumn{2}{|c|}{$\begin{array}{l}\text { Size of Houses Demolished } \\
\text { (hundred square meters) }\end{array}$} \\
\hline - Demolitions in the District & $\begin{array}{l}-0.0103 * * * \\
{[0.0042]}\end{array}$ & $\begin{array}{l}-0.0109 * * \\
{[0.0049]}\end{array}$ & $\begin{array}{l}-0.0381 * \\
{[0.0214]}\end{array}$ & $\begin{array}{l}-0.0417 * \\
{[0.0232]}\end{array}$ \\
\hline - Other Demolitions in the Region & $\begin{array}{l}-0.0026 \\
{[0.0026]}\end{array}$ & $\begin{array}{l}-0.0007 \\
{[0.0028]}\end{array}$ & $\begin{array}{r}-0.00979 \\
{[0.0145]}\end{array}$ & $\begin{array}{l}0.00448 \\
{[0.0178]}\end{array}$ \\
\hline District Fixed Effects & Yes & Yes & Yes & Yes \\
\hline Year Fixed Effects & Yes & Yes & Yes & Yes \\
\hline Economic and Demographic Controls & Yes & Yes & Yes & Yes \\
\hline Other Proxies for Counter-terrorism & No & Yes & No & Yes \\
\hline District Specific Linear Time Trends & Yes & No & Yes & No \\
\hline Number of Observations & 1,008 & 704 & 1,008 & 704 \\
\hline
\end{tabular}

Sources: Authors' calculations using house demolition and fatality data from B'Tselem, suicide terrorism data from ISA, economic and demographic characteristics data from the Palestinian Labor Force Survey, and curfews data from UN OCHA. The data set covers the period October 2000 to December 2005.

Notes: Each column in each panel presents the results of a different regression estimated via panel poisson regression model. Dependent variable is the suicide terror attacks originating in locality i at month t. The economic and demographic controls are the same ones used in specifications 2, 3, 5, and 6 in Table 5. Other proxies for counterterrorism are Israeliinduced Palestinian fatalities and curfews, as used in specifications 3 and 6 in Table 5. Robust standard errors, adjusted for clustering at the district level, in brackets; * indicates statistically significant at $10 \%$ level; ** indicates statistically significant at $5 \%$ level; *** indicates statistically significant at $1 \%$ level. 
Table 12

The Effect Precautionary House Demolitions on the Number of Suicide Attacks

\begin{tabular}{|c|c|c|c|c|}
\hline \multirow[b]{2}{*}{ Variable } & \multicolumn{2}{|c|}{ Data Aggregated at District Level } & \multicolumn{2}{|c|}{ Terror Data at Locality Level } \\
\hline & Entire Sample & Excluding Rafah & Entire Sample & Excluding Rafah \\
\hline Number of Houses Demolished & $\begin{array}{c}0.0193 \\
{[0.0137]}\end{array}$ & $\begin{array}{l}0.0497 * * * \\
{[0.0167]}\end{array}$ & $\begin{array}{c}0.0077 \\
{[0.0109]}\end{array}$ & $\begin{array}{l}0.0239 * * \\
{[0.0105]}\end{array}$ \\
\hline Number of Apartment Units Demolished & $\begin{array}{c}0.0103 \\
{[0.0103]}\end{array}$ & $\begin{array}{l}0.0413 * * * \\
{[0.0139]}\end{array}$ & $\begin{array}{c}0.0025 \\
{[0.0072]}\end{array}$ & $\begin{array}{c}0.0184 \\
{[0.0118]}\end{array}$ \\
\hline Number of Residents in Demolished Houses & $\begin{array}{c}0.0018 \\
{[0.0017]}\end{array}$ & $\begin{array}{l}0.0038 * * * \\
{[0.0016]}\end{array}$ & $\begin{array}{c}0.0008 \\
{[0.0017]}\end{array}$ & $\begin{array}{c}0.0017 \\
{[0.0014]}\end{array}$ \\
\hline Size of House Demolished (hundred square meters) & $\begin{array}{c}0.0066 \\
{[0.0058]}\end{array}$ & $\begin{array}{l}0.0344 * * * \\
{[0.0113]}\end{array}$ & $\begin{array}{c}0.0016 \\
{[0.0042]}\end{array}$ & $\begin{array}{l}0.0140 * \\
{[0.0075]}\end{array}$ \\
\hline Number of Observations & 384 & 360 & 989 & 966 \\
\hline
\end{tabular}

Sources: Authors' calculations using house demolition and fatality data from B'Tselem, suicide terrorism data from ISA, economic and demographic characteristics data from the Palestinian Labor Force Survey, and curfews data from UN OCHA. The data set covers the period March 2004 to December 2005.

Notes: Each column in each panel presents the results of a different regression estimated via panel Poisson regression model. Dependent variable in panel $\mathrm{A}$ is the number of suicide terror attacks originating in district $\mathrm{i}$ at month $\mathrm{t}$. Dependent variable in panel $\mathrm{B}$ is the number of suicide terror attacks originating in locality $i$ at month $t$. All specifications control for economic and demographic conditions, other proxies for counterterrorism, district fixed effects and years fixed effects as in specification 7 in Table 5 . Robust standard errors, adjusted for clustering at the district level, in brackets; * indicates statistically significant at $10 \%$ level; ** indicates statisticallv significant at $5 \%$ level: $* * *$ indicates statisticallv significant at $1 \%$ level. 
Table A.1

The Effect of Punitive House Demolitions on the Number of Suicide Attacks using a Negative Binomial Model

\begin{tabular}{|c|c|c|c|c|c|c|c|c|}
\hline \multirow[b]{2}{*}{ Variable } & \multicolumn{4}{|c|}{ All data aggregated at the district level } & \multicolumn{4}{|c|}{ Using data at the locality level } \\
\hline & $(1)$ & $(2)$ & (3) & (4) & $(5)$ & $(6)$ & $(7)$ & $(8)$ \\
\hline Number of Houses Demolished & $\begin{array}{l}-0.0559 * * * \\
{[0.0212]}\end{array}$ & $\begin{array}{l}-0.0579 * * * \\
{[0.0228]}\end{array}$ & $\begin{array}{l}-0.0493 * * * \\
{[0.0201]}\end{array}$ & $\begin{array}{l}-0.0586 * \\
{[0.0320]}\end{array}$ & $\begin{array}{l}-0.0633 * * * \\
{[0.0268]}\end{array}$ & $\begin{array}{l}-0.0649 * * \\
{[0.0282]}\end{array}$ & $\begin{array}{l}-0.0573 * * \\
{[0.0270]}\end{array}$ & $\begin{array}{l}-0.0621 * \\
{[0.0340]}\end{array}$ \\
\hline Number of Apartment Units Demolished & $\begin{array}{l}-0.0593 * * \\
{[0.0205]}\end{array}$ & $\begin{array}{l}-0.0614 * * * \\
{[0.0218]}\end{array}$ & $\begin{array}{l}-0.0545 * * * \\
{[0.0190]}\end{array}$ & $\begin{array}{l}-0.0629 * * \\
{[0.0291]}\end{array}$ & $\begin{array}{l}-0.0662 * * \\
{[0.0269]}\end{array}$ & $\begin{array}{l}-0.0681 * * * \\
{[0.0285]}\end{array}$ & $\begin{array}{l}-0.0608 * * \\
{[0.0269]}\end{array}$ & $\begin{array}{l}-0.0664 * \\
{[0.0342]}\end{array}$ \\
\hline Number of Residents in Demolished Houses & $\begin{array}{l}-0.0121 * * * \\
{[0.0047]}\end{array}$ & $\begin{array}{l}-0.0126 * * * \\
{[0.0050]}\end{array}$ & $\begin{array}{l}-0.0121 * * * \\
{[0.0050]}\end{array}$ & $\begin{array}{l}-0.0126 * * * \\
{[0.0051]}\end{array}$ & $\begin{array}{l}-0.0136 * * * \\
{[0.0044]}\end{array}$ & $\begin{array}{l}-0.0141 * * * \\
{[0.0046]}\end{array}$ & $\begin{array}{l}-0.0133 * * * \\
{[0.0046]}\end{array}$ & $\begin{array}{l}-0.0136 * * * \\
{[0.0053]}\end{array}$ \\
\hline Size of House Demolished (hundred square meters) & $\begin{array}{l}-0.0417 * * * \\
{[0.0174]}\end{array}$ & $\begin{array}{l}-0.0453 * * * \\
{[0.0193]}\end{array}$ & $\begin{array}{l}-0.0414 * * \\
{[0.0192]}\end{array}$ & $\begin{array}{l}-0.0486 * \\
{[0.0274]}\end{array}$ & $\begin{array}{l}-0.0483 * * \\
{[0.0217]}\end{array}$ & $\begin{array}{l}-0.0504 * * \\
{[0.0233]}\end{array}$ & $\begin{array}{l}-0.0468 * * \\
{[0.0238]}\end{array}$ & $\begin{array}{l}-0.0524 * \\
{[0.0303]}\end{array}$ \\
\hline Locality Fixed Effects & Yes & Yes & Yes & Yes & Yes & Yes & Yes & Yes \\
\hline Year Fixed Effects & Yes & Yes & Yes & Yes & Yes & Yes & Yes & Yes \\
\hline Economic and Demographic Controls & No & Yes & Yes & Yes & No & Yes & Yes & Yes \\
\hline Other Proxies for Counter-terrorism & No & No & No & Yes & No & No & No & Yes \\
\hline District Specific Linear Time Trends & No & No & Yes & No & No & No & Yes & No \\
\hline Number of Observations & 1,008 & 1,008 & 1,008 & 704 & 2,666 & 2,666 & 2,666 & 1,849 \\
\hline
\end{tabular}

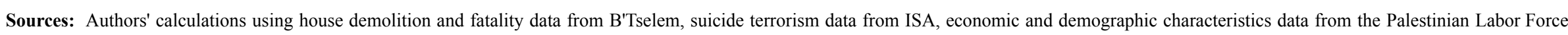
Survey, and curfews data from UN OCHA. The data set covers the period October 2000 to December 2005.

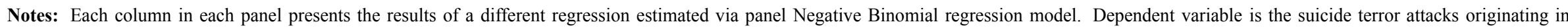

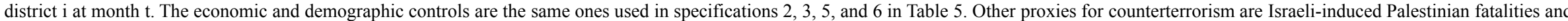

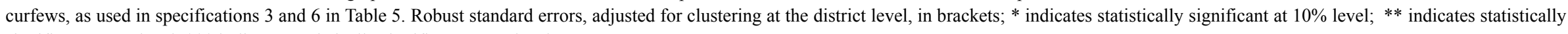
significant at $5 \%$ level; $* * *$ indicates statistically significant at $1 \%$ level. 
Table A.2

The Effect of Punitive House Demolitions on the Number of Suicide Attacks (from September 2001 to December 2005)

\begin{tabular}{|c|c|c|c|c|c|c|c|c|}
\hline \multirow[b]{2}{*}{ Variable } & \multicolumn{4}{|c|}{ All data aggregated at the district level } & \multicolumn{4}{|c|}{ Using data at the locality level } \\
\hline & $(1)$ & $(2)$ & (3) & $(4)$ & $(5)$ & $(6)$ & $(7)$ & $(8)$ \\
\hline Number of Houses Demolished & $\begin{array}{l}-0.0701 * * * \\
{[0.0174]}\end{array}$ & $\begin{array}{l}-0.07144^{* * *} \\
{[0.0230]}\end{array}$ & $\begin{array}{l}-0.05544^{* * *} \\
{[0.0208]}\end{array}$ & $\begin{array}{l}-0.0492 * * \\
{[0.0230]}\end{array}$ & $\begin{array}{l}-0.0702 * * * \\
{[0.0245]}\end{array}$ & $\begin{array}{l}-0.07144^{* * *} \\
{[0.0267]}\end{array}$ & $\begin{array}{l}-0.05777^{* *} \\
{[0.0264]}\end{array}$ & $\begin{array}{l}-0.0560 * * \\
{[0.0284]}\end{array}$ \\
\hline Number of Apartment Units Demolished & $\begin{array}{l}-0.0725 * * \\
{[0.0167]}\end{array}$ & $\begin{array}{l}-0.0745 * * * \\
{[0.0223]}\end{array}$ & $\begin{array}{l}-0.0618 \text { *** } \\
{[0.0202]}\end{array}$ & $\begin{array}{l}-0.0539 * * * \\
{[0.0207]}\end{array}$ & $\begin{array}{l}-0.0725 * * \\
{[0.0247]}\end{array}$ & $\begin{array}{l}-0.0745 \text { *** } \\
{[0.0270]}\end{array}$ & $\begin{array}{l}-0.0616 * * \\
{[0.0265]}\end{array}$ & $\begin{array}{l}-0.0604 * * \\
{[0.0292]}\end{array}$ \\
\hline Number of Residents in Demolished Houses & $\begin{array}{l}-0.0149 * * * \\
{[0.0039]}\end{array}$ & $\begin{array}{l}-0.0158 * * * \\
{[0.0050]}\end{array}$ & $\begin{array}{l}-0.0138 * * * \\
{[0.0048]}\end{array}$ & $\begin{array}{l}-0.0115 * * * \\
{[0.0042]}\end{array}$ & $\begin{array}{l}-0.0149 * * * \\
{[0.0040]}\end{array}$ & $\begin{array}{l}-0.0158 * * * \\
{[0.0046]}\end{array}$ & $\begin{array}{l}-0.0138 * * * \\
{[0.0046]}\end{array}$ & $\begin{array}{l}-0.0126 * * * \\
{[0.0047]}\end{array}$ \\
\hline Size of House Demolished (hundred square meters) & $\begin{array}{l}-0.0539 * * * \\
{[0.0152]}\end{array}$ & $\begin{array}{l}-0.0548 * * * \\
{[0.0188]}\end{array}$ & $\begin{array}{l}-0.0460 \text { *** } \\
{[0.0194]}\end{array}$ & $\begin{array}{l}-0.0410 * * \\
{[0.0204]}\end{array}$ & $\begin{array}{l}-0.0539 * * * \\
{[0.0206]}\end{array}$ & $\begin{array}{l}-0.0548 \text { *** } \\
{[0.0221]}\end{array}$ & $\begin{array}{l}-0.0459 * * \\
{[0.0230]}\end{array}$ & $\begin{array}{l}-0.0465 * \\
{[0.0260]}\end{array}$ \\
\hline Locality Fixed Effects & Yes & Yes & Yes & Yes & Yes & Yes & Yes & Yes \\
\hline Year Fixed Effects & Yes & Yes & Yes & Yes & Yes & Yes & Yes & Yes \\
\hline Economic and Demographic Controls & No & Yes & Yes & Yes & No & Yes & Yes & Yes \\
\hline Other Proxies for Counter-terrorism & No & No & No & Yes & No & No & No & Yes \\
\hline District-Specific Linear Time Trends & No & No & Yes & No & No & No & Yes & No \\
\hline Number of Observations & 832 & 832 & 832 & 704 & 2,193 & 2,193 & 2,193 & 1,849 \\
\hline
\end{tabular}

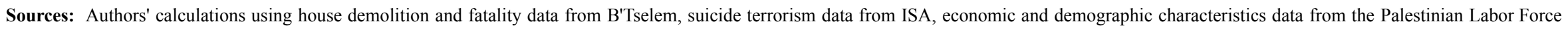
Survey, and curfews data from UN OCHA. The data set covers the period October 2000 to December 2005.

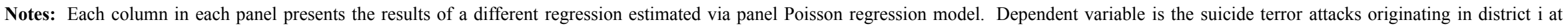

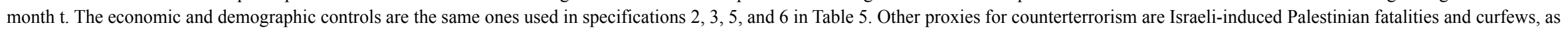

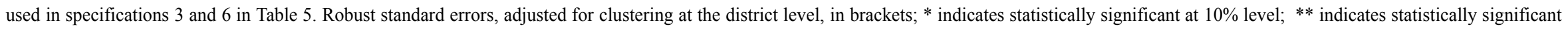
at $5 \%$ level; ${ }^{* * *}$ indicates statistically significant at $1 \%$ level. 